\title{
GLYPHOSATE-RESISTANT SOYBEANS YIELD IN FUNCTION OF GLYPHOSATE SALTS, DOSES AND STADIUM PHENOLOGICAL
}

\author{
PRODUTIVIDADE DE CULTIVARES DE SOJA EM FUNÇÃO DOS SAIS DE \\ GLYPHOSATE, DOSES E ÉPOCAS DE APLICAÇÃO
}

\section{Lucas Alfonso ROHR ${ }^{1}$; Rafaela CINELLI ${ }^{1}$; Rubens Antonio POLITO ${ }^{1}$; Tamara HECK ${ }^{1}$; Noryam Bervian BISPO ${ }^{2}$; Anderson Luis NUNES ${ }^{1}$}

1. Federal Institute of Education, Science and Technology of Rio Grande do Sul - IFRS, Sertão - RS, Brazil. Ecophysiology and Weed Management Group - GEMPLA. anderson.nunes@sertao.ifrs.edu.br. 2. Federal Institute of Education, Science and Technology of Rio Grande do Sul - IFRS, Sertão - RS, Brazil. Laboratory of Biochemistry and Molecular Biology. noryam.bispo@sertao.ifrs.edu.br

\begin{abstract}
Given the importance of soybean to the global economy and as a food source, improving crop management techniques is integral to obtaining higher yields. As such, this study aimed to assess the yield of soybean cultivars as a function of different glyphosate salt formulations, doses and application times. Two field experiments were conducted simultaneously using a randomized block design and $3 \times 4 \times 2$ factorial scheme, with three repetitions. Factor A consisted of three glyphosate formulations: isopropylamine salt (Roundup Original ${ }^{\circledR}$ ), ammonium salt (Roundup $\mathrm{WG}^{\circledR}$ ), and potassium salt (Zapp Qi ${ }^{\circledR}$ ), factor B four application times: 0 , 14, 28, 42 days after planting (DAP), and factor $\mathrm{C}$ two doses: the recommended dose of 720 grams of acid equivalent per hectare and twice that (1440 grams of acid equivalent per hectare). There was no difference between the glyphosate salts for the BMX Ativa $\mathrm{RR}^{\circledR}$ cultivar, but yields of BMX Apolo $\mathrm{RR}^{\circledR}$ submitted to ammonium salt were $28 \%$ higher than those recorded for the other salts studied. Glyphosate potassium salt resulted in lower soybean yields. Potassium salt application between 14 and 28 DAP caused greater toxicity in both the soybean cultivars analyzed.
\end{abstract}

KEYWORDS: Isopropylamine salt. Potassium salt. Ammonium salt. Growth habit. Glycine max.

\section{INTRODUCTION}

Soybean (Glycine max (L.) Merrill) is the main commodity in Brazilian agribusiness (CONAB 2018), the primary source of vegetable oil and a major protein source. In Brazil, the planted area was 35.1 million hectares in the 2017/2018 growing season, with 118 million metric tons produced and an average yield per hectare of $3,333 \mathrm{~kg}$, a $9.3 \%$ increase in relation to the previous year (CONAB, 2018).

Given its importance, improving crop management techniques is vital to the global food supply (ZADINELLO et al., 2012). This includes weed management, which ensures crops achieve their full yield potential. Chemical weed control in the form of pre- and postemergent herbicides is the most common method in soybean crops.

Glyphosate is the main active ingredient used worldwide (GAUPP-BERGHAUSEN et al., 2015). This broad-spectrum herbicide is widely applied as a postemergence weed killer in glyphosate-resistant crops, with more than 150 commercial brands sold around the world in over 160 countries, registered for more than 100 crops (VELINI et al., 2009). It acts by inhibiting the biosynthesis of aromatic amino acids via the precursor enzyme EPSPs (5-enolpyruvylshikimate3-phosphate synthase), preventing shikimate transformation into chorismate (SENSEMAN, 2007).

Resistant cultivars such as RR soybean contain the gene cp4-epsps, which encodes a glyphosate-tolerant enzyme that prevents glyphosate binding, making plants insensitive to the herbicide (BRADSHAW et al., 1997; DUKE; POWLES, 2008). Glyphosate formulations contain several different types of salts, including isopropylamine, potassium and ammonium salt (BRADBERRY; PROUDFOOT; VALE, 2004).

Glyphosate salts can negatively affect plants that carry the glyphosate-resistant gene (ALBRECHT et al., 2011; LONDO et al., 2014; PINTO et al., 2016), and their application times can also influence soybean development. For example, RR soybean and maize crop yields were lower when glyphosate was applied with plants in full bloom as opposed to later stages (ZADINELLO et al., 2012; THOMAS et al., 2017).

Knowing the factors that trigger the negative effects of glyphosate in soybean crops is important in order to establish application guidelines that ensure maximum herbicide performance. This study aimed to assess the yield of soybean cultivars 
as a function of different glyphosate salt formulations, doses and application times.

\section{MATERIAL AND METHODS}

Two experiments were conducted simultaneously in red nitisol, in the municipality of Sertão, Rio Grande do Sul (RS) state, Brazil $\left(28^{\circ} 02^{\prime} 33^{\prime \prime S}, 52^{\circ} 16^{\prime} 03^{\prime \prime} \mathrm{W}\right)$, at an altitude of $705 \mathrm{~m}$. Soil $\mathrm{pH}$, clay and organic matter content were 5.05, $65 \%$ and $2.9 \%$, respectively. The climate in the region is humid subtropical (Cfa) according to Köppen's classification. Rainfall amount and average air temperature by each ten days period (decennial) are shown in Figure 1.

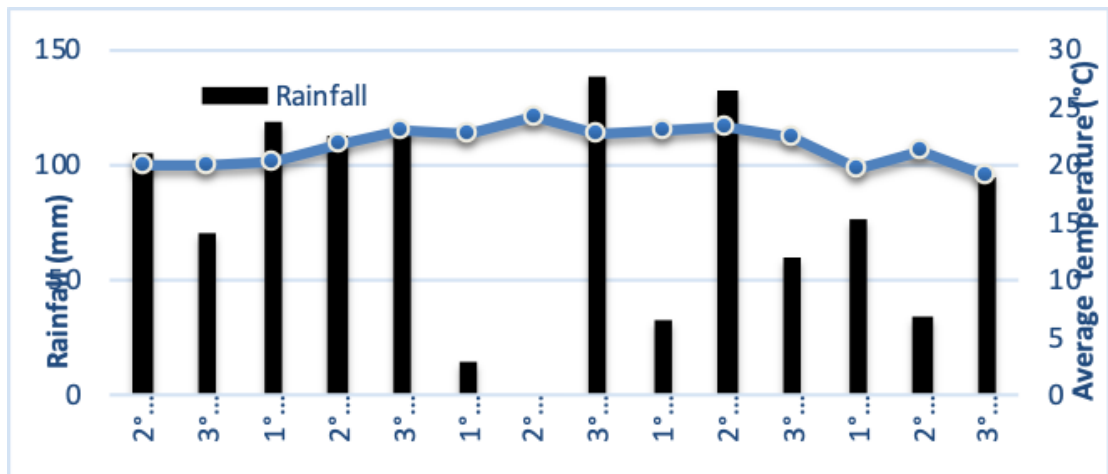

Figure 1. Rainfall amount and average air temperature by each ten days period (decennial) in 2015/16 soybean crop season.

Experiments 1 and 2 were performed with the BMX Apolo $\mathrm{RR}^{\circledR}$ and BMX Ativa $\mathrm{RR}^{\circledR}$ cultivars, respectively. A randomized block design was used for both experiments, with a $3 \times 4 \times 2$ factorial scheme and three repetitions. Factor A consisted of three glyphosate formulations: isopropylamine salt (Roundup Original ${ }^{\circledR}$ ), ammonium salt (Roundup $\mathrm{WG}^{\circledR}$ ), and potassium salt (Zapp Qi ${ }^{\circledR}$ ), factor B four application times: 0, $14,28,42$ days after planting (DAP), and factor C two doses: the recommended dose of 720 grams of acid equivalent per hectare and twice that (1440 grams of acid equivalent per hectare).

Planting was performed on $11 / 19 / 2015$ using a broadcast spreader (Semeato ${ }^{\circledR}$ SHM 13/17), equipped for seven rows spaced $0.45 \mathrm{~m}$ apart. Fertilization was carried out based on soil analysis and crop treatments were established in line with technical recommendations for soybean crops. The plots were kept weed-free. Glyphosate was applied using a $\mathrm{CO}_{2}$-pressurized sprayer, equipped with a boom held $0.5 \mathrm{~m}$ away from the target, containing four ceramic spray nozzles (Micron 110.02/Air) spaced $0.5 \mathrm{~m}$ apart, with a flow rate of $200 \mathrm{~L} \mathrm{ha}^{-1}$. At the time of glyphosate application at $0,14,28$ and 42 DAP the average temperature was 23.3; $21.2 ; 26.5$ and $22.1{ }^{\circ} \mathrm{C}$, respectively. Relative humidity was $68,78,57$ and $82 \%$, respectively. Wind speed was 4.4; 3.3; 5.0 and $2.8 \mathrm{~m} \mathrm{~s}^{-1}$, respectively.
Manual harvesting of the study area $\left(4.7 \mathrm{~m}^{2}\right)$ of the plot was performed on $03 / 29 / 16$, when the crop had reached maturity. The harvested plants were threshed in a stationary thresher and the samples weighed, with water content corrected to $13 \%$ and grain yield expressed in $\mathrm{kg} \mathrm{ha}^{-1}$.

The variables were submitted to analysis of variance (ANOVA) using ASSISTAT software (SILVA and AZEVEDO, 2002). When necessary, the data were transformed to square root plus one to stabilize variances for analysis. Cultivar was considered a random variable, and the other main effects of treatments were tested for cultivarassociated error based on the interaction of other treatments. Data were pooled across cultivars when no significant cultivar-treatment interaction occurred. Treatment means were compared using Tukey's test at $p \leq 0.05$.

\section{RESULTS AND DISCUSSION}

Potassium salt glyphosate spraying as a function of application times altered crop yield (Table 1). The lowest yields were observed for application at 14 days after planting (DAP) in the BMX Ativa RR cultivar, and 28 DAP for BMX Apolo RR (Table 1). A comparison of the cultivars between the two experiments indicated different behavior in relation to potassium salt application (Table 1). BMX Apolo RR was less affected by this formulation at 14 DAP when compared to BMX 
Ativa RR; however, the opposite was observed at 28 DAP. The isopropylamine and ammonium salt formulations showed no effect on soybean yield as a function of application times in either experiment. The average yield of the experiments was lower compared to the soybean grain yield of soybean to previous years. This was due to the lack of precipitation in the first three weeks of January (Figure 1).
Similar result happened when isopropylamine salt application at stages $\mathrm{V}_{6}$ and $\mathrm{R}_{2}$ of the CD $219 \mathrm{RR}^{\circledR}$ cultivar did not affect yield, but spraying at stage $\mathrm{R}_{2}$ resulted in a $14 \%$ decline in the V-TOP ${ }^{\circledR}$ cultivar in relation to treatments applied at $\mathrm{R}_{4}$ and $\mathrm{R}_{5}$ (ZADINELLO et al., 2012). Applying 720 $\mathrm{g}$ a.e $\mathrm{ha}^{-1}$ of isopropylamine, potassium and ammonium salt at 20,35 and 50 DAP resulted in different yields in BRS $244 \mathrm{RR}^{\circledR}$ and M-SOY $7979 R^{\circledR}{ }^{\circledR}$, with a $20 \%$ decrease in the former (AGOSTINETTO et al., 2009).

Table 1. Yield $\left(\mathrm{kg} \mathrm{ha}^{-1}\right)$ of the soybean cultivars BMX Ativa RR and BMX Apolo RR as a function of glyphosate isopropylamine, potassium and ammonium salt application at 0, 14, 28 and 42 days after planting.

\begin{tabular}{|c|c|c|c|c|c|c|c|c|}
\hline \multirow{3}{*}{ Variety } & \multicolumn{8}{|c|}{ Days After Planting } \\
\hline & 0 Day & & 14 Days & & 28 Days & & 42 Days & \\
\hline & \multicolumn{8}{|c|}{ Isopropylamine Salt } \\
\hline BMX Ativa RR & 1361.05 & $\mathrm{~ns}$ & 1434.34 & & 1624.79 & & 1786.83 & \\
\hline \multirow[t]{2}{*}{ BMX Apolo RR } & 1639.84 & & 1332.85 & & 1293.91 & & 1932.66 & \\
\hline & \multicolumn{8}{|c|}{ Potassium Salt } \\
\hline BMX Ativa RR & 1499.43 & $\mathrm{aAB}$ & 1147.55 & bB & 1753.74 & $\mathrm{aA}$ & 2002.43 & $\mathrm{aA}$ \\
\hline \multirow[t]{2}{*}{ BMX Apolo RR } & 1855.81 & $\mathrm{aA}$ & 1700.87 & $\mathrm{aAB}$ & 1184.49 & bB & 1925.35 & $\mathrm{aA}$ \\
\hline & \multicolumn{8}{|c|}{ Ammonium Salt } \\
\hline BMX Ativa RR & 1751.79 & $\mathrm{~ns}$ & 1890.59 & & 2381.06 & & 1948.74 & \\
\hline BMX Apolo RR & 1824.32 & & 2571.49 & & 2508.73 & & 2087.20 & \\
\hline
\end{tabular}

Means followed by the same lower case letter in the column do not differ according to Tukey's test at $5 \%$.

There were no differences between the isopropylamine and ammonium salt formulations for interaction between dose and application times (Table 2). A difference in yield was observed for potassium salt as a function of dose (Table 2), with lower yields in BMX Ativa $\mathrm{RR}^{\circledR}$ at $28 \mathrm{DAP}$ for a dose of $720 \mathrm{~g}$ a.e ha ${ }^{-1}$ in relation to $1440 \mathrm{~g}$ a.e ha ${ }^{-1}$. For the BMX Apolo $\mathrm{RR}^{\circledR}$ cultivar at 14 and 42 DAP, yield was lower when $720 \mathrm{~g}$ a.e $\mathrm{ha}^{-1}$ was applied than $1440 \mathrm{~g}$ a.e $\mathrm{ha}^{-1}$. However, at 0 DAP yield was higher at a dose of $720 \mathrm{~g}$ a.e ha ${ }^{-1}$ (Table 2).

In an experiment with $\mathrm{CD} 214 \mathrm{RR}^{\circledR}$, in which 720 and $1440 \mathrm{~g}$ a.e ha ${ }^{-1}$ of isopropylamine salt was applied at 25 DAP, no differences in yield were observed (ALBRECHT et al., 2014). Similarly, a study with the M-SOY 8888-RR soybean cultivar found no differences between treatments of 720 and $1440 \mathrm{~g}$ a.e $\mathrm{ha}^{-1}$ of isopropylamine salt applied 31 days after emergence (FOLONI et al., 2005). Moreover, no yield differences were reported in a study with the CD $219 \mathrm{RR}^{\circledR}$ cultivar in which 1440 $\mathrm{g}$ a.e ha $^{-1}$ of Roundup Original ${ }^{\circledR}$ herbicide was applied at stages $V_{6}$ and $R_{2}$. However, for each additional gram of acid equivalent applied per hectare, yield declined by $0.4 \mathrm{~kg} \mathrm{ha}^{-1}$ (ALBRECHT et al., 2011).
A $720 \mathrm{~g}$ a.e $\mathrm{ha}^{-1}$ dose of isopropylamine and potassium salt formulations at 14 and 28 DAP reduced soybean yield when compared to ammonium salt application. Probably, under these conditions, isopropylamine and potassium salts allow greater glyphosate absorption in the plant and consequently present higher toxicity. However no differences were observed between glyphosate formulations for $1440 \mathrm{~g}$ a.e $\mathrm{ha}^{-1}$ (Table 3). In a greenhouse-based study with the M-SOY 8925 RR cultivar, $0 ; 500 ; 1000 ; 1500$ and $2000 \mathrm{~g}$ a.e ha ${ }^{-1}$ of isopropylamine and potassium salt were sprayed onto plants at $41 \mathrm{DAP}$, with no differences between the doses and salts applied (REIS et al., 2010). In the M-SOY 8867 RR cultivar, spraying 360 and 720 $\mathrm{g}$ a.e $\mathrm{ha}^{-1}$ of glyphosate isopropylamine salt at planting showed crop selectivity, but $1440 \mathrm{~g}$ a.e $\mathrm{ha}^{-1}$ reduced grain yield by $25 \%$ (PEREIRA et al., 2016). 
Table 2. Yield $\left(\mathrm{kg} \mathrm{ha}^{-1}\right)$ of the soybean cultivars BMX Ativa RR and BMX Apolo RR as a function of different doses of glyphosate acid equivalent applied at different times, using isopropylamine, potassium and ammonium salt formulations.

\begin{tabular}{|c|c|c|c|c|c|c|c|}
\hline & \multicolumn{7}{|c|}{ Variety } \\
\hline \multirow{4}{*}{$\begin{array}{l}\text { Days } \\
\text { After } \\
\text { Planting }\end{array}$} & \multicolumn{4}{|c|}{ BMX Ativa RR } & \multicolumn{3}{|c|}{ BMX Apolo RR } \\
\hline & \multicolumn{7}{|c|}{ Doses } \\
\hline & $720 \mathrm{~g}_{\text {a.e }} \mathrm{ha}^{-1}$ & & $1440 \mathrm{~g}$ a.e $\mathrm{ha}^{-1}$ & $720 \mathrm{~g}_{\text {a.e }} \mathrm{ha}^{-1}$ & & $1440 \mathrm{~g}$ a.e $\mathrm{ha}^{-1}$ & \\
\hline & \multicolumn{7}{|c|}{ Isopropylamine Salt } \\
\hline 0 Day & 1320.47 & ns & 1401.64 & 1454.24 & & 1825.44 & \\
\hline 14 Days & 1524.31 & & 1344.37 & 1383.14 & & 1282.56 & \\
\hline 28 Days & 1371.61 & & 1877.98 & 1310.66 & & 1277.16 & \\
\hline \multirow[t]{2}{*}{42 Days } & 2128.46 & & 1445.20 & 1743.00 & & 2122.33 & \\
\hline & \multicolumn{7}{|c|}{ Potassium Salt } \\
\hline 0 Day & 1285.29 & A & 1713.58 & 2375.96 & A & 1335.67 & $\mathrm{~B}$ \\
\hline 14 Days & 1119.92 & A & 1175.18 & 1331.57 & B & 2070.16 & A \\
\hline 28 Days & 1356.51 & B & 2150.97 & 1165.90 & A & 1203.09 & A \\
\hline \multirow[t]{2}{*}{42 Days } & 2057.79 & A & 1947.07 & 1414.56 & B & 2436.15 & A \\
\hline & \multicolumn{7}{|c|}{ Ammonium Salt } \\
\hline 0 Day & 1561.80 & $\mathrm{~ns}$ & 1941.79 & 1687.49 & & 1961.15 & \\
\hline 14 Days & 1517.39 & & 2263.80 & 2484.49 & & 2658.48 & \\
\hline 28 Days & 2811.05 & & 1951.07 & 2670.86 & & 2346.61 & \\
\hline 42 Days & 1277.83 & & 2619.65 & 2166.49 & & 2007.92 & \\
\hline
\end{tabular}

Means followed by the same upper case letter in the row do not differ according to Tukey's test at 5\%.

Table 3. Average yield $\left(\mathrm{kg} \mathrm{ha}^{-1}\right)$ of the BMX Ativa RR and BMX Apolo RR soybean cultivars as a function of different glyphosate formulations (isopropylamine, potassium and ammonium salt) and application at $0,14,28$ and 42 DAP in different acid equivalent doses.

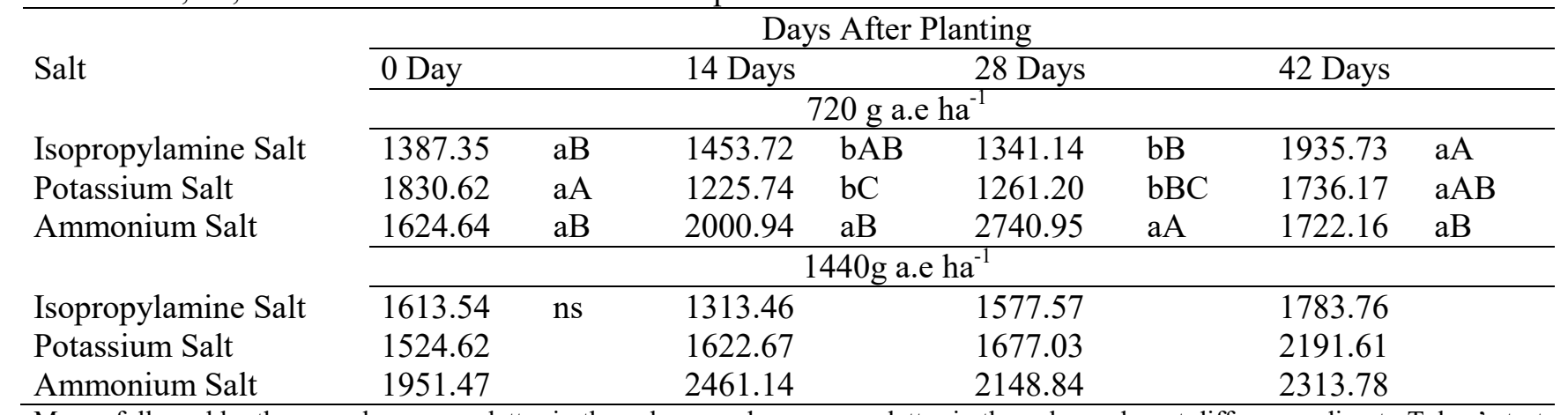

Means followed by the same lower case letter in the column and upper case letter in the column do not differ according to Tukey's test at $5 \%$.

Spray application of glyphosate isopropylamine salt showed no toxicity to the crop as a function of application times (Figure 2A), but significant effects were observed for potassium and ammonium salts (Figures $2 \mathrm{~B}$ and $2 \mathrm{C}$, respectively). The highest selectivity was observed for potassium salt application at 0 and 42 DAP and ammonium salt at 14, 28 and 42 DAP. With respect to the individual effect of the dose for each type of glyphosate salt, differences were only observed for potassium salt (Figures 2D to 2F). Glyphosate potassium salt at $720 \mathrm{~g}$ a.e ha ${ }^{-1}$ reduced the soybean grain yield compared with $1440 \mathrm{~g}$ a.e ha ${ }^{-1}$ dose. This kind of result could be expected in a scenario with high weed infestation. Because, the lower dose means less weed control and consequently greater interference. However, the experiments were performed in areas with low infestation and weeds were controlled weekly. Doses of $720 \mathrm{~g}$ a.e ha ${ }^{-1}$ and $1440 \mathrm{~g}$ a.e $\mathrm{ha}^{-1}$ of isopropylamine or potassium salt applied at 25 DAP did not differ in CD 214 RR cultivar (ALBRECHT et al., 2014). 


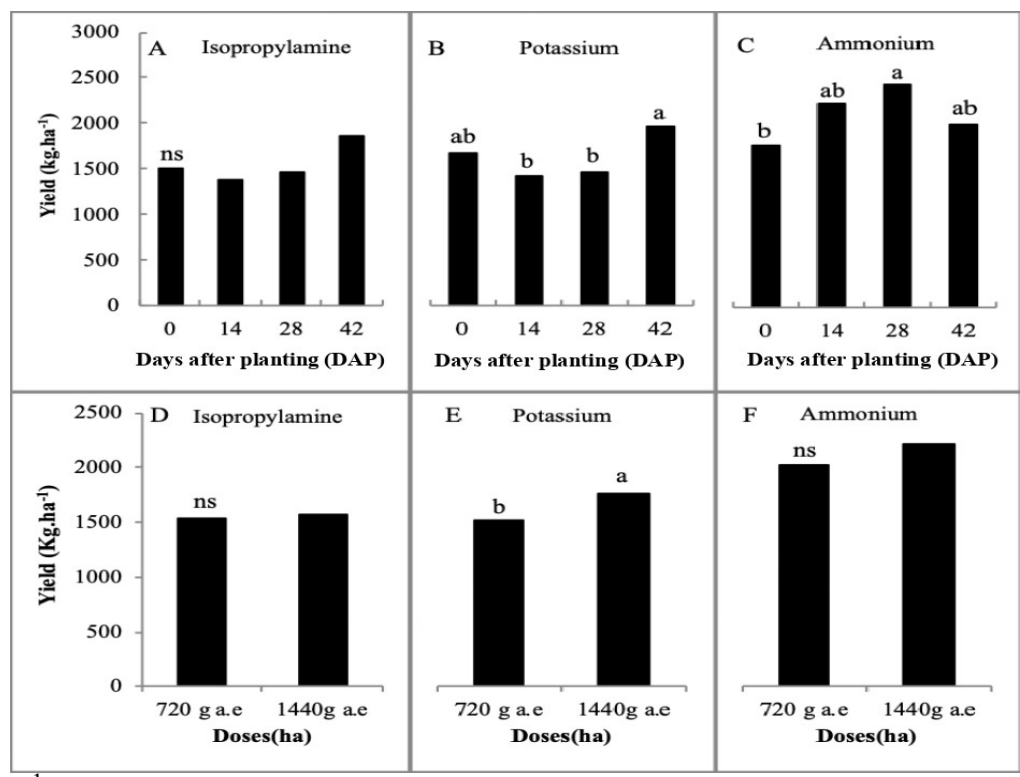

Figure 2. Yield ( $\mathrm{kg} \mathrm{ha}^{-1}$ ) (average of two experiments) as a function of different application times and acid equivalent doses, using different glyphosate formulations (isopropylamine salt (A and D), potassium salt (B and E) and ammonium salt (C and F)).

BMX Ativa $\mathrm{RR}^{\circledR}$ exhibited no differences in glyphosate tolerance as a function of the type of salt applied (Figure 3A), while isopropylamine and potassium salt were the least selective for BMX Apolo $\mathrm{RR}^{\circledR}$ (Figure 3B). The effects of glyphosate isopropylamine salt differ between the M-SOY 8585 RR, P98R91 RR, Valiosa RR, CD 219 RR and TMG 108 RR cultivars (PETTER et al., 2007). Isopropylamine and ammonium salt formulations
(720 g a.e ha ${ }^{-1}$ ) applied to TMG 125 RR at 25 DAP in two growing seasons showed no heterogeneity (REIS et al., 2014). Similarly, in an experiment with CD $214 \mathrm{RR}$ involving the application of $720 \mathrm{~g}$ a.e $\mathrm{ha}^{-1}$ and $1440 \mathrm{~g}$ a.e ha $\mathrm{h}^{-1}$ of isopropylamine and potassium salt at $25 \mathrm{DAP}$, no differences were observed between the salt types at $720 \mathrm{~g}_{\text {a.e }} \mathrm{ha}^{-1}$ (ALBRECHT et al., 2014).

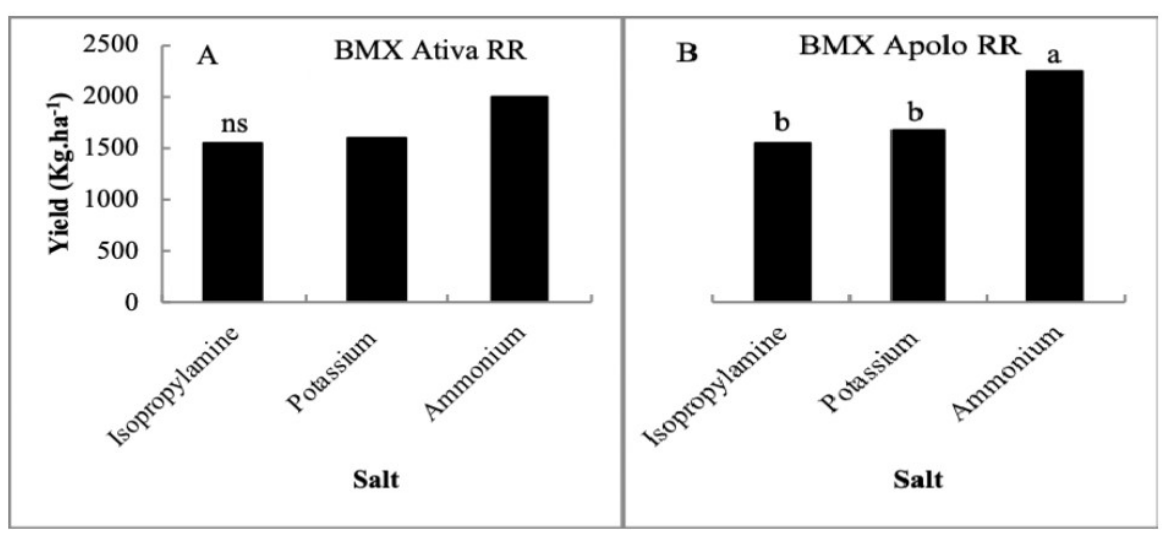

Figure 3. Yield of BMX Ativa RR (C) and BMX Apolo RR (D) as a function of different glyphosate salts.

Contrasting results have been observed for glyphosate selectivity to soybean cultivars. Glyphosate tolerance in soybean varies as a function of the cultivar used, dose, type of salt and application time. The divergent results in the literature may be related to the environment. Welladapted species or cultivars under optimal nutritional conditions are better able to tolerate stress (TAIZ; ZEIGER, 2009). Greater phosphorus availability in the soil reduced phytointoxication by glyphosate isopropylamine salt at doses of 900 and 1800 g a.e ha ${ }^{-1}$ in the TMG 132 RR soybean cultivar (CASONATTO et al., 2014). In this respect, management practices that contribute to crop development and control weed populations tend to mitigate the unwanted effects of glyphosate herbicides. In addition to reducing weed populations and thereby lowering the glyphosate doses needed, the use of winter cover crops improves soil fertility 
and helps retain water in the surface layers, contributing to better crop growth.

\section{CONCLUSION}

Glyphosate potassium salt resulted in lower soybean yields. Potassium salt application between
14 and 28 DAP caused greater toxicity in both the soybean cultivars analyzed. No differences were observed between 720 and $1440 \mathrm{~g}$ a.e ha ${ }^{-1}$ doses for the isopropylamine and ammonium salts.

RESUMO: Diante da importância da cultura da soja tanto na economia mundial quanto para a alimentação, a melhoria das técnicas de cultivo torna-se um ponto fundamental na obtenção de maiores produtividades. Desta forma o objetivo do trabalho foi avaliar a produtividade de cultivares de soja sob a influência da aplicação de diferentes sais de glyphosate, doses e épocas de aplicação. Dois experimentos de campo foram realizados simultaneamente em delineamento de blocos casualizados com arranjo trifatorial $(3 \times 4 \times 2)$ com três repetições. O fator A consistiu de três formulações de glyphosate: sal de isopropilamina (Roundup Original ${ }^{\mathbb{B}}$ ), sal de amônio (Roundup $\mathrm{WG}^{\circledR}$ ), sal de potássio (Zapp Qi ${ }^{\circledR}$ ). O fator B consistiu de quatro épocas de aplicação: 0,14, 28, 42 dias após a semeadura (DAS). $\mathrm{O}$ fator $\mathrm{C}$ consistiu em duas doses: a dose recomendada de 720 gramas de equivalente ácido por hectare e duas vezes a dose recomendada com 1440 gramas de equivalente ácido por hectare. Para a cultivar BMX Ativa $R^{\circledR}$ não se observou diferença quanto aos sais, porém a cultivar BMX Apolo $\mathrm{RR}^{\circledR}$ submetida a aplicação de sal de amônio demostrou uma produtividade $28 \%$ superior em relação aos demais sais. O glyphosate na formulação sal de potássio apresentou redução da produtividade da cultura da soja. Aplicações de glyphosate na formulação sal de potássio realizadas entre os 14 e 28 dias após a semeadura causam maior toxidez em ambas cultivares de soja utilizadas.

PALAVRAS-CHAVE: Sal de isopropilamina. Sal de potássio. Sal de amônio. Hábito de crescimento. Glycine max.

\section{REFERENCES}

AGOSTINETTO, D.; DAL MAGRO, T.; GALON, L.; MORAES, P. V. D.; TIRONI, S. P. Respostas de cultivares de soja transgênica e controle de plantas daninhas em função de épocas de aplicação e formulações de glyphosate. Planta Daninha, v. 27, n. 4, p. 739-746, 2009. http://dx.doi.org/10.1590/S010083582009000400012

ALBRECHT, L. P.; BARBOSA, A. P.; SILVA, A. F. M.; MENDES, M. A.; MARASCHI-SILVA, L. M.; ALBRECHT, A. J. P. Desempenho da soja roundup ready sob aplicação de glyphosate em diferentes estádios. Planta Daninha, v. 29, n. 7, p. 585-590, 2011. http://dx.doi.org/10.1590/S0100-83582011000300012

ALBRECHT, L. P.; ALBRECHT, A. J. P.; BRACCINI, A. L.; OLIVEIRA JR., R. S.; ZOBIOLE, L. H. S.; ÁVILA, M. R. The role of glyphosate in RR soybean production and seed quality. Planta Daninha, v. 32, n. 5, p. 401-407, 2014. http://dx.doi.org/10.1590/S0100-83582014000200018

BRADBERRY, S. M.; PROUDFOOT, A. T.; VALE, J. A. Glyphosate poisoning. Toxicological Reviews, v. 23, n. 3, p. 159-167, 2004. https://doi.org/10.2165/00139709-200423030-00003

BRADSHAW, L. D.; PADGETTE, S. R.; KIMBALL, S. L.; WELLS, B. H. Perspectives on glyphosate resistance. Weed Technology, v. 11, n. 1, p. 189-198, 1997. https://doi.org/10.1017/S0890037X00041567

CASONATTO, M. S.; ARANTES, S. A. C. M.; RIEGER, E. A.; ANDRADE, E. A. How glyphosate may affect transgenic soybean in different soil and phosphorus levels. Planta Daninha, v. 32, n. 4, p. 843-850, 2014. http://dx.doi.org/10.1590/S0100-83582014000400019

CONAB. Acompanhamento da safra brasileira de grãos. 9. Brasília: CONAB, 2018. 178 Disponível em: < www.conab.gov.br >. Acesso em 20/02/2019. 
DUKE, S. O.; POWLES, S. B. Glyphosate: a once-in-a-century herbicide. Pest Management Science, v. 64, n. 4, p. 319-325, 2008. https://doi.org/10.1002/ps.1518

FOLONI, L. L.; RODRIGUES, D.; FERREIRA, F.; MIRANDA, R.; ONO, E. O. Aplicação de glifosato em pós-emergência, em soja transgênica cultivada no cerrado. Revista Brasileira de Herbicidas, v. 4, n. 3, p. 47 58, 2005. https://doi.org/10.7824/rbh.v4i3.36

GAUPP-BERGHAUSEN, M.; HOFER, M.; REWALD, B.; ZALLER, J. G. Glyphosate-based herbicides reduce the activity and reproduction of earthworms and lead to increased soil nutrient concentrations. Scientific reports, v. 5, p. 12886, 2015. https://doi.org/10.1038/srep12886.

LONDO, J. P.; MCKINNEY, J.; SCHWARTZ, M.; BOLLMAN, M.; SAGERS, C.; WATRUD, L. Sub-lethal glyphosate exposure alters flowering phenology and causes transient male-sterility in Brassica spp. BMC Plant Biology, v. 14, n. 1, p. 70, 2014. https://doi.org/10.1186/1471-2229-14-70

PEREIRA, C. S.; BEVILACQUA, U. C.; SOUZA, T. V.; MATTE, W. D.; CHAPLA, M. V. Phytotoxicity in transgenic soybean treated with glyphosate doses. Scientific Electronic Archives, v. 9, n. 3, p. 52-61, 2016.

PETTER, F. A.; PROCÓPIO, S. O.; CARGNELUTTI FILHO, A.; BARROSO, A. L. L.; PACHECO, L. P. Manejo de herbicidas na cultura da soja Roundup Ready®. Planta Daninha, v. 25, n. 4, p. 557-566, 2007. http://dx.doi.org/10.1590/S0100-83582007000300015

PINTO, C. C.; OLIVEIRA, C. O.; AMÉRICO, G. H. P.; VAZQUEZ, G. H.; LAZARINI, E. Efeito da dose e da época de aplicação do glifosato na produção e na qualidade da soja RR. Revista de Ciências Agrárias, v. 39, n. 2, p. 310-317, 2016. http://dx.doi.org/10.19084/RCA15076

REIS, T. C.; NEVES, A. F.; ANDRADE, A. P.; SANTOS, T. S. Efeitos de fitotoxidade na soja RR tratada com formulações e dosagens de glifosato. Revista de Biologia e Ciências da Terra, v. 10, n. 1, p. 34-43, 2010.

REIS, M. R.; REIS, R. M.; ALMEIDA, W. L.; CARVALHO, A. M. X.; RONCHI, C. P.; DIAS, R. C. Micorrização, nodulação e produção da soja roundup ready após a aplicação de diferentes formulações de glyphosate. Planta Daninha, v. 32, n. 3, p. 563-569, 2014. http://dx.doi.org/10.1590/S010083582014000300012.

SENSEMAN, S. A. Herbicide handbook. 9. ed. Lawrence: Weed Science Society of America, 2007. 458 p.

TAIZ, L.; ZEIGER, E. Fisiologia Vegetal. 4. ed. Porto Alegre: Artmed, 2009. 848 p.

THOMAS, W. E.; PLINE-SRNÍC, W. A. P.; THOMAS, J. F.; EDMISTEN, K. L.; WELLS, R.; WILCUT, J. W. Glyphosate negatively affects pollen viability but not pollination and seed set in glyphosate-resistant corn. Weed Science, v. 52, n. 5, p. 725-734, 2017. https://doi.org/10.1614/WS-03-134R

VELINI, E. D.; MESCHEDE, D. K.; CARBONARI, C. A.; TRINDADE, M. L. B. Glyphosate. 1. ed. Botucatu: Fepaf, 2009. 496 p.

ZADINELLO, R.; CHAVES, M. M.; SANTOS, R. F.; BASSEGIO, D.; WERNCKE, I. Influência da aplicação de glifosato na produtividade da soja. Acta Iguazu, v. 1, n. 4, p. 1-8, 2012. 